\title{
PENGETAHUAN REMAJA PUTRI TENTANG MENARCHE
}

\author{
${ }^{1}$ Delfriana Ayu A, ${ }^{2}$ Prodalima Sinulingga \\ ${ }^{\text {I} P r o g r a m ~ S t u d i ~ I l m u ~ K e s e h a t a n ~ M a s y a r a k a t, ~ U n i v e r s i t a s ~ I s l a m ~ N e g e r i ~ S u m a t e r a ~ U t a r a, ~ I n d o n e s i a ~}$ \\ ${ }^{2}$ Program Studi Ilmu Keperawatan, STIKes Nurul Hasanah Kutacane, Indonesia \\ Email: ${ }^{1}$ delfrianaayu@uinsu.ac.id, 2prodalima@gmail.com
}

\begin{abstract}
ABSTRAK
Menarche merupakan simtoms atau tanda terjadinya transisi status sosial dari masa anak-anak ke masa dewasa, dan terdapat perubahan lainnya seperti payudara yang mulai tumbuh, pertumbuhan rambut di daerah kemaluan dan bagian ketiak. Tujuan penelitian ini adalah untuk mengetahui tingkat pengetahuan remaja putri tentang menarche secara umum, umur dan sumber informasi. Jenis penelitian ini adalah deskriptif dengan pendekatan cross sectional. Metode pengambilan sampel dalam penelitian ini menggunakan total sampling. Sampel penelitian adalah remaja putri yang duduk di bangku SMP yaitu sebanyak 115 orang dengan waktu penelitian di bulan April 2020. Hasil penelitian menunjukkan, responden paling banyak memiliki pengatahuan baik yaitu 53 responden, berdasarkan umur, mayoritas berada pada umur >13 tahun yaitu sebanyak 68 orang (59\%) dan berdasarkan sumber informasi, mayoritas responden mendapatkan sumber informasi tentang menarche dari keluarga terutama ibu yaitu sebanyak 78 orang (68\%). Kesimpulan yang dapat ditarik dari penelitian ini adalah pengetahuan remaja putri tentang menarche paling banyak memiliki pengetahuan baik, berdasarkan umur mayoritas berada pada umur >13 tahun dan berdasarkan sumber informasi mayoritas berasal dari keluarga. Diharapkan agar melakukan kerjasama dengan instansi kesehatan dalam hal meningkatkan pengetahuan remaja putri seputar menarche dan kesehatan reproduksi baik dalam bentuk peningkatan penyebaran informasi menggunakan media elektronik maupun informasi tertulis yang tersedia di ruang publik.
\end{abstract}

Kata Kunci : Menarche, Pengetahuan, Remaja Putri.

\section{ABSTRACT}

Menarche is a symptom or sign of a transition in social status from childhood to adulthood, and there are other changes such as breasts that begin to grow, hair growth in the pubic area and axillary areas. The purpose of this study was to determine the level of knowledge of young women about menarche in general, age and source of information. This type of research is descriptive with cross sectional approach. The sampling method in this study uses total sampling. The sample of the study was young women who sat in junior high school, as many as 115 people with the time of research in April 2020. The results showed that the most respondents had good knowledge, namely 53 respondents, based on age, the majority were at age> 13 years, as many as 68 people (59\%) and based on sources of information, the majority of respondents get sources of information about menarche from families, especially mothers, as many as 78 people (68\%),. The conclusion that can be drawn from this research is that the knowledge of young women about menarche has the most good knowledge, based on the age of the majority who are> 13 years old and based on the majority of information sources come from families. It is expected to collaborate with health institutions in terms of increasing the knowledge of young women around menarche and reproductive health in the form of increased information dissemination using electronic media and written information available in public spaces.

Keywords: Knowledge, Menarce, Young Women.

\section{PENDAHULUAN}

Masa remaja merupakan suatu periode dalam lingkaran kehidupan diantara masa kanak-kanak dan masa dewasa. Masa remaja remaja adalah suatu bagian dari proses tumbuh kembang yang berkesinambungan sejak saat konsepsi sampai mencapai masa dewasa (Narendra 2002). Badan Kesehatan Dunia mengatakan bahwa jumlah remaja dunia pada tahun 2009 mencapai $\pm 1,2$ milyar dan dari 5 orang remaja, 1 diantaranya adalah remaja. Di wilayah bagian Asia Tenggara sendiri, jumlah remaja mencapai \pm 18 sampai dengan $25 \%$ dari seluruh populasi. (WHO, 2009).

Menstruasi pertama bisa menjadi saat yang meresahkan bagi remaja putri, hal tersebut sering diiringi dengan seringkali kondisi emosional yang mencerminkan rasa takut, cemas dan membingungkan. Perasaan 
semacam itu bias ditimbulkan olehn karena kurangnya atau salahnya informasi yang didapat anak mengenai menstruasi (Djiwandono, 2008).

Menarche atau istilah yang paling dikenal sebagai haid pertama adalah keluarnya darah dari dingding Rahim seorang wanitapertama kali pada masa hidupnya sehingga hal tersebut menandakan bahwa seorang wanita sudah masuk pada periode aqil balikh secara agama dan matang untuk memulai bereproduksi. Menarche adalah menstruasi yang dialami pertama kali oleh seorang perempuan (Bobak et al, 2004).

Menarche merupakan tanda adanya suatu perubahan status sosial dari anak - anak ke masa dewasa, dan adanya perubahan lain seperti pertumbuhan payudara, pertumbuhan rambut pada daerah pubis dan aksila, dan distribusi lemak pada daerah pinggul (Proverawati \& Misaroh, 2009).

Menarche adalah haid yang pertama terjadi yang merupakan ciri khas kedewasaan seorang wanita yang sehat dan tidak hamil (Mitayani \& Sartika, 2010). Biasanya menarche rata-rata terjadi pada usia 11-13 tahun. Namun dalam dasawarsa terakhir ini, usia menarche telah bergeser ke usia yang lebih muda (Wiknjosastro, 2008).

Hasil Survei Kesehatan Reproduksi Remaja Indonesia (2007) menunjukkan bahwa tingkat pengetahuan remaja tentang Kesehatan Reproduksi Remaja (KRR) rendah, yaitu pengetahuan remaja perempuan tentang menstruasi bahwa merupakan tanda dari berfungsinya sistem reproduksi wanita yaitu sekitar 6,5\%. Menurut (Iswarati, 2011) mengatakan bahwa pengetahuan remaja di Indonesia tentang KRR relatif masih rendah, terutama berkaitan dengan pengetahuan akilbalig dan masa subur yaitu sebesar $39,6 \%$.

Hasil penelitian (Novitasari et al, 2018) yang melakukan penelitian tentang hubungan pengetahuan tentang menstruasi dengan kesiapan dalam menghadapi menarche menunjukkan sebanyak 13 responden $(37,2 \%)$ memiliki pengetahuan baik, 11 responden $(31,4 \%)$ dengan pengetahuan cukup, dan 11 responden $(31,4 \%)$ memiliki pengetahuan kurang. Hasil penelitian (Susila, 2015) tentang gambaran pengetahuan remaja putri tentang menarcheterhadap 30 remaja putri mengatakan,remaja yang memiliki pengetahuan baik sebanya 13 responden (43\%) cukup 14 responden (47\%) kurang 3 responden $(10 \%)$.

Berdasarkan hasil penelitian yang dilakukan oleh (Indarsita et al, 2017) tentang pengetahuan dan kesiapan remaja putri dalam menghadapi menarche kepada 82 remaja putri, hasil penelitiannya menunjukkan bahwa tingkat pengetahuan remaja putri tentang menarche (menstruasi pertama) dikategorikan cukup sebanyak 39 orang $(47,6 \%)$ sedangkan kategori kurang sebanyak 16 orang $(19,5 \%)$.

Remaja yang akan mengalami menarche membutuhkan kesiapan mental yang baik. Kesiapan menghadapi menarche adalah suatu kondisi siapnya seorang wanita untuk mencapai salah satu kematangan fisik secara biologi yaitu datangnya haid pertama. Hasil penelitian (Leliana, 2010), responden yang memiliki pengetahuan baik sebanyak 21 orang $(95,5 \%)$ dengan sikap positif, pengetahuan baik dengan sikap negatif sebanyak 1 orang $(4,5 \%)$, pengetahuan tidak baik 12 orang $(63,2 \%)$ dengan sikap, sedangkan pengetahuan tidak baik dengan sikap negatif sebanyak 7 orang $(36,8 \%)$. Sehingga kesimpulan yang dapat ditarik adalah terdapat hubungan yang signifikan antara pengetahuan remaja putri dengan kesiapan dalam menghadapi menarche.

Menurut (Yudha, 2012) dalam penelitiannya tentang kesiapan remaja putri menghadapi menarche mengatakan bahwa sebagian besar dari responden penelitiannya menyatakan siap menghadapi menarche yaitu 22 responden (62,9\%), sedangkan yang menyatakan tidak siap yakni 13 responden $(37,1 \%)$. Hal ini dapat terjadi oleh karena pengetahuan remaja putri dan informasi yang didapat sudah cukup baik sehingga berdampak pada kesiapan yang positif pada diri. Hasil penelitian (Jayanti, 2011), menunjukkan bahwa mayoritas responden penelitian mengatakan tidak siap dalam menghadapi menarche yaitu sebesar 48 orang $(92,30 \%)$, sedangkan selebihnya mengatakan siap sebesar 4 orang anak $(7,69 \%)$.

Berdasarkan survei pendahuluan yang dilakukan oleh peneliti terhadap 25 orang remaja putri yang duduk di bangku SMP, didapatkan hasilnya bahwa 13 orang remaja putri memahami dan tahu tentang menarche dengan baik, 7 orang memahai dengan cukup 
baik dan 5 orang pengetahuannya masih berada pada kategori kurang. Maka dari itu peneliti tertarik membahas dan melakukan penelitian lebih lanjut tentang pengetahuan remaja putri tentang menarche.

\section{METODE PENELITIAN}

Jenis Penelitian ini adalah deskriptif dengan pendekatan cross sectional. Penelitian dilakukan pada bulan April 2020. Populasi dalam penelitian ini adalah siswi yang duduk di bangku SMP. Sampel merupakan unit terkecil dari populasi. Teknik pengambilan sampling yang digunakan adalah total sampling dimana, keseluruhan populasi dijadikan sebagai subjek penelitian yaitu sebanyak 115 orang siswi yang duduk di bangku SMP. Dengan Kriteria :

1. Bersedia menjadi responden.

2. Mampu menggunakan internet.

Metode Pengumpulan Data

1. Peneliti mneyiapkan butir pertanyaan dalam bentuk kuesioner terbuka.

2. Kuesioner diadopsi dari penelitian (Utami, 2019) yang kemudian disesuaikan dan selanjutnya dibagi kepada responden.

3. Peneliti menjelaskan kepada responden tentang tujuan, manfaat, dan prosedur pengisian kuesioner.

4. Peneliti mengajukan lembar persetujuan menjadi responden.

5. Responden diberikan waktu lebih kurang 15 menit untuk mengisi kuesioner yang telah dibagi.

6. Responden diberikan kesempatan untuk bertanya bila ada yang tidak mengerti atau ada yang kurang jelas.

\section{Definisi Operasional}

1. Pengetahuan merupakan segala sesuatu yang deketahui oleh responden tentang menarche.

2. Remaja putri merupakan jenis kelamin responden penelitian yang digunakan.

3. Menarche merupakan waktu pertama kali respoden mengalami haid.

\section{HASIL DAN PEMBAHASAN}

\subsection{Hasil}

Tabel 1. Distribusi Frekuensi Pengetahuan Responden tentang Menarche

\begin{tabular}{lcc}
\hline Pengetahuan & Frekuensi & Persentase \\
\hline Baik & 53 & 46 \\
\hline Cukup & 45 & 39 \\
\hline Kurang & 17 & 15 \\
\hline \multicolumn{1}{c}{ Total } & $\mathbf{1 1 5}$ & $\mathbf{1 0 0}$ \\
\hline
\end{tabular}

Berdasarkan tabel diatas, responden paling banyak memiliki pengatahuan baik sebanyak 53 responden (46\%), cukup sebanyak 45 orang (39\%) dan kurang sebanyak 17 orang $(15 \%)$.

Tabel 2. Distribusi Frekuensi Karakteristik Pengetahuan Responden Tentang Menarche Berdasarkan Umur Dan Sumber Informasi

\begin{tabular}{|c|c|c|}
\hline Karakteristik & Frekuensi & Persentase \\
\hline \multicolumn{3}{|l|}{ Umur } \\
\hline 11-12 Tahun & 47 & 41 \\
\hline$>13$ Tahun & 68 & 59 \\
\hline Total & 115 & 100 \\
\hline \multicolumn{3}{|c|}{ Sumber Informasi } \\
\hline Keluarga & 78 & 68 \\
\hline Tenaga Kesehatan & 15 & 13 \\
\hline Media Cetak & 8 & 7 \\
\hline Media Elektronik & 14 & 12 \\
\hline Total & 115 & 100 \\
\hline
\end{tabular}

Berdasarkan dari tabel 2, mayoritas responden berada pada umur $>13$ tahun yaitu sebanyak 68 orang (59\%) dan umur 11-12 tahun sebanyak 47 orang $(41 \%)$ dan berdasarkan sumber informasi, mayoritas responden mendapatkan sumber informasi tentang menarche dari keluarga yaitu sebanyak 78 orang $(68 \%)$, dari tenaga kesehatan sebanyak 15 orang (13\%), media elektronik sebanyak 14 orang (12\%) dan dari media cetak sebanyak 8 orang (7\%).

\subsection{Pembahasan}

\section{Pengetahuan Remaja Tentang Menarche}

Berdasarkan hasil penelitian didapatkan hasilnya bahwa responden paling banyak memiliki pengatahuan baik sebanyak 53 orang (46\%), cukup sebanyak 45 orang (39\%) dan kurang sebanyak 17 orang (15\%). Hasil penelitian ini sejalan dengan yang dilakukan oleh (Anggraeni et al, 2018) dimana pengetahuan remaja putri sebagian besar memiliki pengetahuan baik tentang 
menstruasi yaitu sebanyak 23 responden $(60,52 \%)$.

(Sunaryo, 2004) mengatakan, pengetahuan merupakan domain yang sangat penting untuk terbentuknya perilaku terbuka dan terbentuknya suatu perilaku didasari oleh adanya pengetahuan yang mendorong seseorang untuk melakukan suatu tindakan. Pengetahuan merupakan hasil tahu, yang terjadi setelah orang melakukan penginderaan terhadap suatu objek tertentu, pengetahuan hasil dominan yang sangat penting untuk terbentuknya tindakan seseorang. Dengan pengetahuan akan membuat seseorang lebih melihat cara dan kesempatan untuk meningkatkan derajat hidup dan pengetahuan akan mempengaruhi sikap dan perbuatan seseorang untuk berperilaku atau hidup sehat. Dengan demikian seseorang akan mampu melakukan sesuatu yang dianggap baik bila memiliki pengetahuan cukup (Notoatmodjo, 2012).

\section{Pengetahuan Remaja Putri Tentang Menarche Berdasarkan Umur Dan Sumber Informasi}

Berdasarkan hasil penelitian, pengetahuan responden berdasarkan umur mayoritas berada pada umur $>13$ tahun yaitu sebanyak 68 orang (59\%) dan umur 11-12 tahun sebanyak 47 orang (41\%). Menurut (Green, 2005), umur merupakan faktor penentu dalam tingkat pengetahuan, pengalaman, keyakinan dan motivasi, sehingga umur mempengaruhi perilaku seseorang terhadap objek tertentu.

Menurut (Meliono, 2007), umur mempengaruhi tingkat pengetahuan seseorang. Umur yang semakin bertambah maka pengalaman yang dimiliki juga akan semakin banyak dan beragam. Semakin muda umur seseorang akan mempengaruhi tingkat pengetahuan dan cara menjaga kebersihan alat kelamin saat menstruasi (Soekidjo, 2003). Ini erat hubungannya dengan umur responden yang mayoritas adalah 16-19 tahun yang merupakan remaja tahap akhir.

Berdasarkan hasil penelitian, mayoritas responden mendapatkan sumber informasi tentang menarche dari keluarga terutama ibu yaitu sebanyak 78 orang (68\%), dari tenaga kesehatan sebanyak 15 orang (13\%), media elektronik sebanyak 14 orang (12\%) dan dari media cetak sebanyak 8 orang $(7 \%)$. Dalam penelitian ini, sumber utama penyampaian informasi tentang menarche kepada remaja putri adalah ibu, dimana ibu merupakan sumber rujukan pertama anak usia remaja dalam mendapatkan sumber informasi tentang menarche kemudian tenaga kesehatan yang ada disekitar lingkungan remaja baik tenaga kesehatan yang brasal dari puskesmas, rumah sakit ataupun dinas kesehatan.

\section{KESIMPULAN}

Kesimpulan yang dapat ditarik dari penelitian ini adalah pengetahuan remaja putri tentang menarche paling banyak memiliki pengetahuan baik, berdasarkan umur mayoritas berada pada umur $>13$ tahun dan berdasarkan sumber informasi mayoritas berasal dari keluarga.

\section{REFERENCES}

Anggraeni W., \& Sari K.I.P. (2018). Hubungan Pengetahuan Remaja Tentang Menstruasi Dengan Tingkat Kecemasan Dalam Menghadapi Menarche Pada Siswi Kelas IV Dan V SDI Darul Hikmah Krian Sidoarjo. Jurnal Nurse and Health. Vol. 7 (1) : 80-85.

Bobak I. M, Lowdermilk \& Jensen. (2004). Buku Ajar Keperawatan Maternitas. Edisi 4. Jakarta : EGC.

BKKBN. (2007). Survei Kesehatan Reproduksi Remaja. Jakarta.

Green, W.L. (2005). Health Education Planing A Diagnostik Approach, The Johns Hapkins University: Mayfield Publishing Company.

Indarsita, Dina, \& Purba, Yeni. (2017). Pengetahuan Dan Kesiapan Remaja Putri Dalam Menghadapi Menarche di SD Negeri NO 064023 Medan. Jurnal Ilmiah PANNMED. Vol, 12 (2).

Iswarati, \& Titut Y.P. (2008). Faktor-Faktor yang mempengaruhi Sikap terhadap Perilaku Seksual Pra Nikah pada Remaja di Indonesia. Puslitbang KB dan Kesehatan Reproduksi BKKBN. Jakarta.

Leliana. (2010). Hubungan Pengetahuan Remaja Putri Terhadap Kesiapan Dalam Menghadapi Menarche Di SD $A L-A Z H A R$ Medan. http://repository.usu.ac.id/handle/123456 789/19364. Accesed On March 01, 2020. 
Mitayani \& Wiwi, Sartika. (2010). Buku Saku Ilmu Gizi. Jakarta: Trans Info Media.

Narendra, M.S. (2002). Buku Ajar I Tumbuh Kembang Anak dan Remaja. Edisi Pertama IDAI. Jakarta : Sagung Seto.

Novitasari, Silvia, Wardani, H.E \& Ariwinanti, Desi. (2018). Hubungan Pengetahuan Tentang Menstruasi Dengan Kesiapan Dalam Menghadapi Menarche Pada Siswi SDN Asrikaton 1. Preventia: The Indonesian Journal of Public Health. Vol. 3 (2).

Notoatmodjo, Soekidjo. (2003). Pengembangan Sumber Daya Manusia, Jakarta: Rineka Cipta.

Notoatmodjo, Soekidjo. (2007). Promosi Kesehatan dan Ilmu Perilaku. Jakarta: Rineka Cipta.

Proverawati \& Misaroh. (2009). Menarche Menstruasi Pertama Penuh Makna. Yogyakarta: Nuha Medika.

Sunaryo. (2004). Psikologi Untuk Pendidikan. Jakarta: EGC.
Susila, Ida. (2015). Gambaran Pengetahuan Remaja Putri Tentang Menarche (Studi di SD Negeri Wanar Kecamatan Pucuk Kabupaten Lamongan Tahun 2015). Jurnal MIDPRO. Vol 8 (1).

Utami, Pri, Y.A. (2019). Hubungan Tingkat Pengetahuan Dengan Tingkat Kecemasan Remaja Dalam Menghadapi Menarche Pada Siswi Kelas V Dan VI Di SD Negeri 1 Ceper Klaten Tahun 2019. Skripsi. Politeknik Kesehatan Kementrian Kesehatan Yogyakarta.

Wiknjosastro, Hanafi. (2008). Ilmu Kandungan. Edisi 2. Jakarta: EGC.

WHO. (2009). Guidelines on Hand Hygiene in Health Care. Library Cataloguing-in Publication Data.

Yudha, I.P, \& Untari, Ida. (2012). Hubungan Antara Pengetahuan Dengan Kecemasan Menghadapi Menarche Pada Siswi Kelas VI. http://digilib.unimus.ac.id/dowload.php? $\mathrm{id}=5718$. Accesed On March 02, 2020 